Izvorni znanstveni rad - UDK - 616.895.2-053.6

159.922.8.072

159.97.072-055.52

\title{
Uloga depresivnosti roditelja i roditeljske samoefikasnosti u povezanosti ekonomske prilagodbe i depresivnosti adolescenata
}

\author{
Maja Anđelinović, Ivana Vrselja, Marina Merkaš
}

Odjel za psihologiju, Hrvatsko katoličko sveučilište, Zagreb, Hrvatska

\section{Sažetak}

Polazeći od teorijskih postavki modela obiteljskog stresa cilj je rada bio empirijski provjeriti ostvaruje li ekonomska prilagodba obitelji svoj učinak na izraženost depresivnost kod adolescenata izravno i/ili neizravno, učincima na depresivnost roditelja i osjećaj roditeljske samoefikasnosti. U radu su analizirani podatci prikupljeni od adolescenata $(N=247)$ koji žive u dvoroditeljskim obiteljima te obaju njihovih roditelja, a u okviru projekta "Rad roditelja, ekonomske teškoće obitelji i dobrobit roditelja i djece". Djeca su procijenila svoju depresivnost, a roditelji svoju depresivnost i roditeljsku samoefikasnost te ekonomsku prilagodbu obitelji. Kako bi se provjerilo postojanje izravnog i neizravnog učinka otežane ekonomske prilagode obitelji na izraženost depresivnosti kod adolescenata, provedene su dvije serijalne medijacijske analize (jedna na uzorku očeva i jedna na uzorku majki) u PROCESS makrou za SPPS. Rezultati tih analiza pokazali su kako otežana ekonomska prilagodba obitelji izravno i neizravno, samo preko izražene depresivnosti majke i smanjenog osjećaja roditeljske samoefikasnosti majke, pridonosi izraženijoj depresivnosti kod adolescenata. Neizravan serijalni učinak ekonomske prilagode obitelji na depresivnost adolescenata, putem depresivnosti i roditeljske samoefikasnosti oca, nije se pokazao značajnim. Nalazi rada upućuju na različite procese kojima ekonomska prilagodba obitelji djeluje na ponašanje i doživljavanje roditelja i adolescenata.

Ključne riječi: model obiteljskog stresa, depresivnost, roditeljska samoefikasnost, adolescenti

\section{Uvod}

Hrvatsko društvo posljednjih godina prolazi kroz razdoblje puno izazova, prvenstveno zbog gospodarske krize koja je započela 2008. godine i ostavila značajne posljedice na gospodarstvo (Benić, 2012). Zbog lošega ekonomskog stanja porasla je i stopa nezaposlenosti građana Republike Hrvatske te je ona tako u 2015. godini iznosila visokih 17.4\% (Hrvatski zavod za zapošljavanje, 2016). Dugotrajni

Maja Anđelinović, Odjel za psihologiju, Hrvatsko katoličko sveučilište, Ilica 242, 10000 Zagreb, Hrvatska. E-pošta: maja.andelinovic@unicath.hr 
loši ekonomski čimbenici i nemogućnost zapošljavanja predstavljaju velik rizik za siromaštvo, koje se definira kao pojava kada mjesečni prihodi po članu kućanstva nisu dovoljni za podmirenje životnih troškova (Državni zavod za statistiku, 2016). Prema podatcima za 2015. godinu čak se $20 \%$ hrvatskog stanovništva nalazilo u rizičnoj skupini kojoj prijeti siromaštvo.

Navedeni su podatci zabrinjavajući jer loši ekonomski uvjeti života mogu negativno djelovati na dobrobit i zdravlje pojedinaca, osobito onih najranjivijih djece i mladih. Istraživanja (Bolger, Patterson, Thomskon i Kupersmidt, 1995; Evans, 2004; Gershoff, Aber, Raver i Lennon, 2007; Gottman i Notarius, 2000; Lee, Wickrama i Simons, 2013; McDougall i sur., 2004) dosljedno pokazuju da ekonomske teškoće obitelji nepovoljno djeluju na razvoj djece dovodeći do problema u njihovu ponašanju kao i do internaliziranih problema, poput depresije. Istraživanja općenito pokazuju da je depresivnost učestalija među djecom koja dolaze iz obitelji s ekonomskim teškoćama nego među djecom koja dolaze iz obitelji bez ekonomskih teškoća (McLeod i Shanahan, 1996; Ponnet, 2014; Samaan, 2000; Wadsworth i Achenbach, 2005). Također, istraživanja su pokazala da porast ekonomskih obiteljskih teškoća tijekom vremena dovodi do intenziviranja depresivnih simptoma kod djece (McLeod i Shanahan, 1996; Samaan, 2000) te da život u lošijim ekonomskim uvjetima značajno predviđa povećanje depresivnosti u kasnijim godinama života (Kim, Conger, Elder i Lorenz, 2003).

\section{Mehanizmi djelovanja ekonomskih teškoća obitelji na depresivnost djece}

U literaturi još uvijek ne postoji slaganje oko toga kako ekonomske teškoće obitelji djeluju na prilagodbu djece i mladih, pa tako i na razvoj depresivnosti. Učinke ekonomskih teškoća često je teško izolirati zato što su oni povezani s nizom drugih nepovoljnih okolnosti koje ugrožavaju razvoj djeteta. Istraživači na ovom području najčešće tragaju za varijablama medijatorima, koje objašnjavaju učinke ekonomskih teškoća na djecu, i to u okviru ključnog sustava - obitelji. Obiteljski utemeljeni mehanizmi djelovanja ekonomskih teškoća na prilagodbu djeteta najčešće se proučavaju u okviru modela obiteljskog stresa (engl. Family stress model) (Conger i Elder, 1994). Ovaj model pretpostavlja niz medijacijskih odnosa između ekonomskih teškoća, ekonomskog pritiska, emocionalnih stanja skrbnika, konflikta između skrbnika, roditeljskih ponašanja te prilagodbe djeteta. Ekonomske teškoće u ovom modelu predstavljaju objektivni pokazatelj koji uključuje niske prihode te negativne ekonomske događaje, poput gubitka posla i primanja. Prema ovom se modelu pretpostavlja da će ekonomske teškoće prvenstveno stvarati ekonomski pritisak u obitelji i na taj način djelovati na njezino funkcioniranje i prilagodbu njezinih članova. Ekonomski se pritisak odnosi na pridavanje psihološkog značenja nizu doživljenih ekonomskih teškoća, a uključuje nedovoljno materijalnih prilika da bi se kupila hrana i odjeća, nedovoljno novaca za plaćanje računa i pokrivanje troškova do kraja tekućeg mjeseca te nužnost smanjivanja nepotrebnih troškova (Conger i Donnellan, 2007). Kada se obitelj suoči s ekonomskim pritiskom, roditelji 
počinju doživljavati negativne emocije, poput depresije (Berkowitz, 1989; Conger i Elder, 1994; Conger i sur., 1992, 1993). Posljedično, navedeni emocionalni problemi kod roditelja štetno djeluju na bračnu dinamiku, povećavajući vjerojatnost javljanja konflikata između supružnika. Prema modelu, bračni konflikti oslabljuju kapacitet i sposobnosti roditelja da se posvete djeci, uključe u njihove dnevne aktivnosti te da se prema njima ponašaju toplo i dosljedno; sve to naposljetku dovodi do lošije prilagodbe djece i javljanja određenih problema (Conger i Donnellan, 2007), poput depresije.

U posljednjem je desetljeću proveden velik broj istraživanja provjere modela obiteljskog stresa, uključujući izravne replikacije cijelog ili samo dijelova modela. Općenito, može se zaključiti kako su postavke ovog modela potvrđene u istraživanjima (Benner i Kim, 2010; Conger i sur., 2002; Linver, Brooks-Gunn i Kohen, 2002; Mistry, Vandewater, Huston i McLoyd, 2002; Solantaus, Leinonen i Punamäki, 2004). Nedavno je čak nekoliko autora upozorilo i na mogućnost njegova proširenja te na valjanost njegovih varijacija (Barnett, 2008; Conger, Conger i Martin, 2010; Mistry, Lowe, Benner i Chien, 2008; Scaramella, Sohr-Preston, Callahan i Mirabile, 2008). Tako su Scaramella i sur. (2008), na uzorku majki s izrazito niskim prihodima i njihove djece u dobi od dvije godine, proučavali kako je financijski pritisak povezan s majčinom depresivnošću, osjećajem roditeljske samoefikasnosti te internaliziranim problemima kod djece. Sukladno postavkama modela obiteljskog stresa pokazalo se da su majčina depresivnost i roditeljska samoefikasnost medijatori u odnosu između financijskog pritiska majki i internaliziranih problema kod djece. Točnije, pokazalo se da je izraženiji financijski pritisak kod majki povezan s njihovom izraženijom depresivnošću, a koja je bila povezana s osjećajem smanjene roditeljske samoefikasnosti; manja se roditeljska samoefikasnost naposljetku pokazala povezanom s internaliziranim problemima kod djece.

Dakle, vidljivo je da su Scaramella i sur. (2008) umjesto uključivanja roditeljskog ponašanja u model (kako je to u originalnom modelu obiteljskog stresa postavljeno) uključili osjećaj majčine roditeljske samoefikasnosti. Roditeljska je samoefikasnost kognitivni konstrukt koji se odnosi na vjerovanja roditelja o njihovim vlastitim sposobnostima i uspješnosti u izvršavanju roditeljske uloge i zadaća (Coleman i Karraker, 2000; Keresteš, Brković i Kuterovac-Jagodić, 2011). Roditeljska je samoefikasnost jedna od ključnih odrednica kompetentnoga roditeljskog ponašanja (Jones i Prinz, 2005) te je kao takva povezana sa zdravim razvojem djeteta (Coleman i Karraker, 2003; Gross i Tucker, 1994). Iako je roditeljska samoefikasnost u literaturi prepoznata kao važan i kompleksan konstrukt, malo se zna o tome što ju određuje jer nedostaje istraživanja koji ju sustavno proučavaju. Također, većina je postojećih istraživanja ograničena izostankom čvrstih teorijskih temelja. Na valjanost uključivanja konstrukta roditeljske samoefikasnosti u model obiteljskog stresa upućuju i rezultati još nekih istraživanja osim istraživanja Scaramelle i suradnika (2008). Naime, nekoliko njih pokazalo je da je niža razina 
majčine roditeljske samoefikasnosti povezana $s$ izraženijom majčinom depresivnošću (Gross i Tucker, 1994), kao i to da su veći obiteljski prihodi povezani s izraženijom majčinom roditeljskom samoefikasnošću (Coleman i Karraker, 2000). Tako su Ardelt i Eccles (2001) pronašli da su učinci majčine roditeljske samoefikasnosti najizraženiji u obiteljima koje žive u nepovoljnim okolnostima. Ono što iznenađuje je da se jako malo istraživanja bavilo proučavanjem odnosa navedenih varijabli na uzorcima očeva. U jednom istraživanju koje je uključivalo i očeve i majke Gross i Tucker (1994) su pronašli da je viša roditeljska samoefikasnost povezana s manje izraženim depresivnim simptomima majke, ali ne is depresivnim simptomima oca. Nadalje, Sevigny i Loutzenhiser (2009) navode da se naizgled čini vjerojatnim da će obiteljski prihodi djelovati na očeve procjene roditeljske samoefikasnosti iz razloga što je "othranjivanje djece" važan pokazatelj očeve uključenosti u živote djece (Christiansen i Palkovitz, 2001). Međutim, rezultati su se njihova istraživanja pokazali suprotni polaznim pretpostavkama, odnosno pokazalo se da ukupni obiteljski prihodi nisu značajan prediktor roditeljske samoefikasnosti očeva.

\section{Svrha istraživanja $\mathrm{i}$ hipoteze}

Pregled literature nam pokazuje kako je model obiteljskog stresa potvrđen na različitim uzorcima (Benner i Kim, 2010; Conger i sur., 2002; Mistry i sur., 2002; Linver i sur., 2002; Solantaus i sur., 2004). Međutim, Conger i suradnici (2010) navode smjernice za buduća istraživanja modela obiteljskog stresa te preporučuju provedbu istraživanja i u drugim kulturama, a s ciljem daljnje provjere njegove valjanosti. Slijedeći navedene smjernice i na temelju činjenice da su postavke modela obiteljskog stresa rijetko provjeravane na hrvatskim uzorcima (npr. Rajter, 2013), u ovom će se radu na jednom prigodnom uzorku hrvatskih adolescenata i njihovih roditelja provjeriti postavke navedenog modela. Spoznaje dobivene ovim istraživanjem obogatit će postojeću literaturu s podatcima o valjanosti modela obiteljskog stresa na hrvatskim uzorcima, ali će se i popuniti određene praznine vezane za podatke o roditeljskoj samoefikasnosti. Naime, konstrukt roditeljske samoefikasnosti rijetko je proučavan u okviru nekih teorijskih postavki, a proučavanje je očeve roditeljske samoefikasnosti u literaturi gotovo u potpunosti zanemareno. Dobivenim će se podatcima znatno pridonijeti literaturi jer je njegova glavna svrha provjeriti postavke modela obiteljskog stresa $\mathrm{s}$ roditeljskom samoefikasnošću kao jednom od pretpostavljenih medijatorskih varijabli u odnosu između teže ekonomske prilagodbe obitelji (mjera drugačijeg naziva, ali po sadržaju odgovara konceptu ekonomskog pritiska u modelu obiteljskog stresa) i depresivnosti adolescenata, i to posebno na uzorku majki i očeva. Specifičnije, provjerit će se jesu li roditeljska depresivnost i roditeljska samoefikasnost medijatori u odnosu između teže obiteljske prilagodbe na financijske teškoće i depresivnosti adolescenata.

Polazeći od postavki modela obiteljskog stresa, u radu su postavljene četiri hipoteze. Pretpostavlja se da majčina procjena teže obiteljske ekonomske prilagodbe 
neće pokazati izravan učinak na depresivnost adolescenata (H1), ali da će pokazati neizravan učinak preko izraženijih depresivnih simptoma majke i njezina smanjenog osjećaja roditeljske samoefikasnosti (H2). Također, pretpostavlja se da očeva procjena teže obiteljske ekonomske prilagodbe neće pokazati izravan učinak na depresivnost adolescenata (H3), ali da će pokazati neizravan učinak preko izraženijih depresivnih simptoma oca i njegova smanjenog osjećaja roditeljske samoefikasnosti (H4).

\section{Metoda}

\section{Sudionici}

Rad se temelji na podatcima prikupljenim $u$ prvoj od dvije točke longitudinalnog istraživanja djece i njihovih roditelja. Prvom točkom prikupljanja podataka, provedenom u proljeće 2016. godine, obuhvaćeno je 345 djece (216 djevojčica) prosječne dobi od 15 godina $(S D=1.75)$. Djeca koja su sudjelovala u istraživanju bili su učenici od 6. do 8. razreda iz sedam osnovnih škola iz Grada Zagreba i okolice, te djeca od 1. do 3. razreda iz četiri srednje škole iz Grada Zagreba i okolice.

S obzirom na postavljene ciljeve rada obrađeni su podatci prikupljeni na poduzorku djece koja dolaze iz dvoroditeljskih obitelji, a čija su oba roditelja ispunila upitnike. Iz dvoroditeljskih je obitelji dolazilo 285 djece (176 djevojčica) iz uzorka, a za njih 247 oba su roditelja ispunila upitnike (149 djevojčica). Dakle, u poduzorak je uključeno 247 djece (149 djevojčica) prosječne dobi od 15 godina $(S D=1.73)$ te 494 roditelja (247 majki prosječne dobi od 44 godine $(S D=5.88)$ i 247 očeva prosječne dobi 47 godina $(S D=7.68)$.

U obiteljima iz poduzorka roditelji najviše posjeduju srednjoškolsko (58.1\% očeva i $56.3 \%$ majki) i fakultetsko obrazovanje ( $21 \%$ očeva i $26.7 \%$ majki), dok je najmanje onih koji imaju nezavršenu osnovnu ili završenu osnovnu školu (3.2\% očeva i $3.7 \%$ majki). Većina je roditelja u poduzorku zaposlena, i to najvećim dijelom na neodređeno radno vrijeme (79.7\% očeva i $77.2 \%$ majki), a znatno manje na određeno radno vrijeme ( $8.9 \%$ očeva i $7.5 \%$ majki). Nezaposlenih je očeva bilo najmanje $(3.8 \%)$, dok je nezaposlenih majki bilo relativno više nego nezaposlenih očeva (13.5\%). Naposljetku, u poduzorku je bio zastupljen i određeni udio umirovljenika (7.6\% očeva i $1.9 \%$ majki). Što se tiče prosječnoga mjesečnog prihoda po članu kućanstva, najveći udio roditelja procjenjuje svoje mjesečne prihode u rasponu od 1501 do 2500 kuna (28.6\% očeva i $30 \%$ majki), a odmah potom u rasponu od 2501 do 3500 kuna (24.5\% očeva i $21.9 \%$ majki). Najmanji udio poduzorka roditelja procjenjuje visinu svojih mjesečnih prihoda po članu kućanstva u kategoriji najmanjega mjerenog iznosa, onom koji je manji od 1500 kuna $(8.7 \%$ 
očeva i $10 \%$ majki), dok je $14.5 \%$ očeva i $11.9 \%$ majki procijenilo da se prosječni mjesečni prihodi nalaze u najvišoj mjerenoj kategoriji (iznad 5501 kunu).

\section{Instrumenti}

Podatci prikazani u radu prikupljeni su u okviru istraživanja u kojem je primijenjen opširniji upitnik kojim se mjere različiti aspekti obiteljskog života. Kako bi odgovorili na probleme rada, korišteni su podatci prikupljeni mjerom ekonomske prilagodbe koju su ispunjavali roditelji, mjerom roditeljske samoefikasnosti, koju su također ispunjavali roditelji, mjerom samoprocjene depresivnosti kod roditelja te mjerom samoprocjene depresivnosti kod djece.

Za mjerenje ekonomske prilagodbe obitelji korišteni su pokazatelji ekonomske prilagodbe (engl. economic adjustment) iz rada Eldera, Congera, Fostera i Ardelte (1992) koji se odnose na specifične postupke koje obitelji moraju činiti kako bi "spojile kraj s krajem". Spajanjem originalnih pokazatelja ekonomske prilagodbe i prilagodbom istih u kontekstu života u Hrvatskoj (npr. što obitelji mogu činiti u situacijama financijskih teškoća u Hrvatskoj), od originalnih 17 pokazatelja osmišljeno je 11 pokazatelja ekonomske prilagodbe obitelji, koji su primijenjeni u ovom istraživanju. Od 11 pokazatelja (svi označavaju određeni gubitak), pet pokazatelja označava gubitak financijske neovisnosti (npr. Posudili ste novac da biste platili račune.; Odgodili ste plaćanje računa.; Ugovorili ste kredit ili zajam kako biste podmirili troškove života.; Koristili ste financijsku pomoć države (npr. dječji doplatak, jednokratne pomoći).; Koristili ste ušteđevinu za podmirivanje troškova života.), a šest pokazatelja mjeri gubitak načina života (npr. Prodali ste imovinu/posjed kako biste podmirili troškove života.; Odgodili ste velike kupovine (npr. kupovinu automobila).; Odustali ste od putovanja na ljetovanjel zimovanjelodmor.; Štedjeli ste na troškovima prijevoza (npr. korištenje autobusa, a ne automobila).; Štedjeli ste na troškovima režija (npr. smanjili potrošnju struje, plina, vode).; Odustali ste od odlazaka na koncerte, u kino i/ili u kazalište.). Roditelji su trebali označiti prisutnost ili odsutnost određenog postupka u proteklih godinu dana na svih 11 pokazatelja. Ukupan rezultat na ovoj mjeri formiran je kao prosjek majčinih i očevih procjena na svim pokazateljima i može varirati od 0 do 11 , pri čemu viši rezultat upućuje na otežanu ekonomsku prilagodbu obitelji, odnosno na veće financijske gubitke i gubitke u načinu dosadašnjeg života obitelji. Pouzdanost je mjere ekonomske prilagodbe na ovom poduzorku roditelja zadovoljavajuće visoka i iznosi .79.

Za ispitivanje je depresivnosti kod roditelja korištena subskala depresivnosti iz kratke forme Skale depresivnosti, anksioznosti i stresa (Depression Anxiety Stress Scales, DASS-21; Lovibond i Lovibond, 1995). Zadatak roditelja na ovoj subskali bio je procijeniti izraženost depresivnih simptoma opisanih u sedam čestica (npr. Nisam mogla doživjeti nikakve pozitivne i ugodne osjećaje.; Osjećala sam da se nemam čemu radovati.; Osjećala sam se tužno i potišteno.) u proteklom tjednu na 
skali od četiri stupnja (0 - uopće se ne odnosi na mene; 3 - u potpunosti se odnosi na mene). Budući da ova skala dosada nije bila primjenjivana na hrvatskim uzorcima, eksploratornom je faktorskom analizom provjerena njezina struktura. Na temelju je dobivenih rezultata jedna čestica (Bilo mi je teško pokrenuti se da nešto napravim.) isključena iz formiranja ukupnog rezultata na subskali depresivnosti, a razlog tome je što je pokazala nisku projekciju na faktor depresivnosti i visoku projekciju na faktor anksioznosti. Prema tome, ukupan rezultat na ovoj subskali formiran je kao jednostavna linearna kombinacija odgovora roditelja na šest čestica iz subskale. Teoretski, rezultat može varirati od 0 do 18 , pri čemu viši rezultat označava veću izraženost simptoma depresivnosti. Pouzdanost tipa Cronbachov $\alpha$ je zadovoljavajuće visoka na oba uzorka roditelja $\left(\alpha_{\text {majka }} .86 ; \alpha_{\text {otac }}=.81\right)$.

Roditeljska samoefikasnost mjerena je subskalom roditeljske samoefikasnosti iz Skale roditeljske kompetentnosti (Keresteš i sur., 2011). Subskala se sastoji od pet čestica (npr. Većinu problema koje ima s djetetom mogu lako riješiti.; Mislim da za odgoj svog djeteta imam dovoljno znanja i vještina.; Ja sam osoba koja najbolje razumije što muči svoje dijete.) na kojima roditelji bilježe svoje odgovore na skali od četiri stupnja (1 - uopće se ne slažem; 4 - potpuno se slažem). Rezultat na subskali određen je kao jednostavna linearna kombinacija odgovora na svih pet čestica iz subskale, te on može varirati od 5 do 20 . Viši postignuti rezultat na ovoj subskali označava izraženiju samoprocijenjenu roditeljsku samoefikasnost. Pouzdanost tipa Cronbachov $\alpha$ za ovu subskalu je na oba uzorka roditelja zadovoljavajuće visoka $\left(\alpha_{\text {majka }} .77 ; \alpha_{\text {otac }}=.80\right)$.

Depresivnost djece mjerena je subskalom depresivnosti iz kratke forme Revidirane skale dječje anksioznosti i depresivnosti (Revised Child Anxiety and Depression Scale-Short Version, RCADS; Chorpita, Yim, Moffitt, Umemoto i Francis, 2000). Subskala je namijenjena procjeni simptoma depresije prema DSMIV kriterijima kod djece od 7 do 18 godina. Zadatak sudionika bio je procijeniti koliko često im se događaju simptomi navedeni u šest čestica subskale (npr. Ništa mi više nije zabavno.; Imam problema sa spavanjem.; Imam problema s apetitom.; Jako sam umoran.) na skali od četiri stupnja (1 - nikada; 4 -uvijek). Subskala dosada nije prevedena na hrvatski jezik, što je za potrebe ovog istraživanja učinjeno. Prijevod subskale učinjen je na način da ju je prvo dvoje stručnjaka u području prevelo s engleskog jezika na hrvatski, zatim s hrvatskog na engleski jezik, a naposljetku je lektor provjerio postoje li eventualne razlike u prijevodu. Budući da skala dosada nije bila primijenjena na populaciji hrvatskih adolescenata, pristupilo se i provjeri njezine faktorske strukture postupkom eksploratorne faktorske analize. Faktorska je analiza pokazala jednofaktorsku strukturu subskale te su sve čestice iz subskale uključene u formiranje ukupnog rezultata. Ukupan je rezultat formiran kao jednostavna linearna kombinacija šest čestica. Teoretski raspon se kreće od 6 do 24, a viši rezultat označava veću učestalost simptoma depresivnosti kod djece. Pouzdanost tipa Cronbachov $\alpha$ za ovu subskalu je zadovoljavajuće visoka te ona iznosi .71. 


\section{Postupak}

Provedbu istraživanja odobrilo je Ministarstvo znanosti, obrazovanja i športa te Etičko povjerenstvo Hrvatskoga katoličkog sveučilišta. Istraživanje je provedeno u skladu s Etičkim kodeksom istraživanja za djecu, a financiralo ga je Hrvatsko katoličko sveučilište [iz odobrenog znanstvenoga projekta Hrvatskoga katoličkog sveučilište "Rad roditelja, ekonomske teškoće obitelji i dobrobit roditelja i djece", (HKS-2016-3)]. ${ }^{1}$

Provedba istraživanja započeta je krajem drugog polugodišta u školskoj godini 2015./2016. Prije svega, valja naglasiti da su u istraživanju prikupljeni roditeljski informirani pismeni pristanci na sudjelovanje u istraživanju (za njihovo sudjelovanje te za sudjelovanje njihove djece), kao i informirani pismeni pristanci djece na sudjelovanje u istraživanju. Roditelji su materijale (pristanke i upitnike) dobili na način da su ih njihova djeca donijela kući, gdje se i odvijalo njihovo ispunjavanje. Od 2363 roditelja kojima su poslani materijali, njih je 384 (16\%) potpisalo informirani pismeni pristanak na sudjelovanje u istraživanju i popunilo upitnike. Kako bismo mogli spojiti odgovore roditelja i njihove djece u programu za statističku obradu podataka, roditelji (a poslije i djeca) na upitnike su upisivali zaporke. U istraživanju su sudjelovala samo ona djeca čiji su roditelji dali pismeni pristanak na sudjelovanje $u$ istraživanju i koja su dala svoj vlastiti pismeni pristanak na sudjelovanje $\mathrm{u}$ istraživanju. Na temelju podataka s potpisanih pristanaka formiran je popis djece koja mogu sudjelovati u istraživanju, a prema kojem su stručni suradnici u školama napravili raspored grupnog prikupljanja podataka. Djeca su informirana o svrsi istraživanja, njihovu dobrovoljnom sudjelovanju u istraživanju, povjerljivosti podataka te korištenju podataka isključivo u znanstvene svrhe. Također, ponuđena im je mogućnost da se jave istraživačima odmah nakon popunjavanja upitnika ako imaju bilo kakvih pitanja o samom istraživanju i projektu te ako se osjećaju nelagodno zbog nečega što su doživjela tijekom sudjelovanja u istraživanju. Uz to, rečeno im je da se mogu i naknadno obratiti školskom psihologu ako imaju nekih pitanja o istraživanju i projektu te ako se budu osjećali nelagodno zbog sudjelovanja $\mathrm{u}$ istraživanju. Od djece za koje su prikupljeni roditeljski pristanci na sudjelovanje nijedno dijete nije odbilo sudjelovati u istraživanju. Ispunjavanje upitnika u prosjeku je trajalo oko dvadeset minuta, a kao zahvalu za sudjelovanje $u$ istraživanju djeca su dobila simbolične nagrade, odnosno bilježnice.

${ }^{1}$ Dio je rezultata ovog istraživanja prikazan na 24. godišnjoj konferenciji hrvatskih psihologa (Opatija, 6.-12. studenoga 2016.). 


\section{Rezultati}

Prije obrade podataka kojima će se odgovoriti na probleme postavljene u radu analizirani su deskriptivni podatci za sve varijable koje su uključene u rad te korelacije među njima.

Kako bi se provjerilo postojanje izravnih i neizravnih učinaka teže ekonomske prilagodbe na depresivnost adolescenata kroz roditeljsku depresivnost i samoefikasnost, provedene su dvije serijalne medijacijske analize (jedna na uzorku očeva i jedna na uzorku majki) u PROCESS makrou za SPSS (Hayes, 2012). Ovaj makro identificira nekoliko učinaka prediktorske varijable na kriterijsku varijablu: jedan izravni, tri specifična neizravna učinka (od kojih dva idu kroz svaki pretpostavljeni medijator, a treći ide serijalno kroz oba pretpostavljena medijatora) te totalne učinke (Hayes, Preacher i Myers, 2010). Makro se temelji na bootstrapmetodi testiranja značajnosti neizravnog učinka, koja predstavlja neparametrijski postupak unutar kojeg se regresijski parametri procjenjuju na temelju uzastopnoga, nasumičnog izvlačenja manjih uzoraka sa $n-1$ sudionika iz originalnog uzorka te se računaju prosječne vrijednosti regresijskih koeficijenata izračunatih na takvim manjim uzorcima (Hayes, 2009). Intervali pouzdanosti takvih koeficijenata procjenjuju se na temelju dobivenih empirijskih distribucija rezultata uzoraka na temelju kojih možemo točnije testirati značajnost neizravnih učinaka. Konvencionalno se uzima broj od 5000 bootstrap-uzorkovanja sa 95\% intervalima pouzdanosti (IP). Kako bi se moglo zaključiti da je neizravni učinak relevantan, interval pouzdanosti ne smije uključivati nulu, odnosno da bi učinak bio relevantan, on mora biti različit od nule kako bismo s $95 \%$ sigurnošću mogli zaključiti kako on nije posljedica slučajnog variranja. Naposljetku, važno je napomenuti da ova metoda testiranja medijacije ne zahtijeva da prediktor i kriterij budu značajno povezani, kao što to zahtijeva metoda testiranja medijacije Barona i Kennya (1986).

\section{Analiza deskriptivnih podataka}

Kao što je vidljivo iz Tablice 1., roditelji procjenjuju da njihove obitelji imaju relativno malo poteškoća u ekonomskoj prilagodbi $(M=3.40 ; S D=2.55)$, odnosno da se $\mathrm{u}$ proteklih godinu dana nisu dogodile velike promjene prouzrokovane financijskim teškoćama $u$ smislu gubitka financijske neovisnosti i gubitka dotadašnjeg načina života. Roditelji su procijenili da se kod njih simptomi depresivnosti javljaju izrazito rijetko $\left(M_{\text {majka }}=1.76 ; S D=2.91 ; M_{\text {otac }}=1.16 ; S D=2.14\right)$, dok su adolescenti procijenili da se kod njih simptomi depresivnosti javljaju osrednje učestalo $(M=10.22 ; S D=2.76)$. Naposljetku, i majke i očevi u uzorku su izvijestili da se osjećaju visoko samoefikasnima u roditeljskoj ulozi $\left(M_{m a j k a}=16.69 ; S D=2.13\right.$; $M_{\text {otac }}=16.27 ; S D=2.38$ ). 
Tablica 1. Aritmetičke sredine i standardne devijacije za sve mjerene varijable

\begin{tabular}{lcccc}
\hline & $M$ & $S D$ & $N$ & Postignuti raspon \\
\hline 1. Teža ekonomska prilagodba obitelji & 3.40 & 2.55 & 245 & $0-9$ \\
2. Depresivnost majke & 1.76 & 2.91 & 278 & $0-16$ \\
3. Roditeljska samoefikasnost majke & 16.69 & 2.13 & 281 & $10-20$ \\
4. Depresivnost oca & 1.16 & 2.14 & 259 & $0-14$ \\
5. Roditeljska samoefikasnost oca & 16.27 & 2.38 & 263 & $8-20$ \\
6. Depresivnost adolescenta & 10.22 & 2.76 & 289 & $6-19$ \\
\hline
\end{tabular}

Što se tiče korelacija između varijabli analiziranih u radu, iz Tablice 2. je vidljivo da je teža ekonomska prilagodba obitelji povezana $\mathrm{s}$ izraženijom depresivnošću majke i oca, kao i s izraženijom depresivnošću adolescenata.

Tablica 2. Korelacije među svim mjerenim varijablama

\begin{tabular}{|c|c|c|c|c|c|c|}
\hline & 1 & 2 & 3 & 4 & 5 & 6 \\
\hline 1. Teža ekonomska prilagodba obitelji & - & $.30^{* *}$ & $-.15^{*}$ & $.24^{* *}$ & -.08 & $.21^{* *}$ \\
\hline 2. Depresivnost majke & & - & $-.21^{* *}$ & $.37^{* *}$ & -.11 & $.15^{*}$ \\
\hline 3. Roditeljska samoefikasnost majke & & & - & $-.23^{* *}$ & $.42^{* *}$ & $-.25^{* *}$ \\
\hline 4. Depresivnost oca & & & & - & $-.14^{*}$ & $.19^{* *}$ \\
\hline 5. Roditeljska samoefikasnost oca & & & & & - & $-.13^{*}$ \\
\hline 6. Depresivnost adolescenta & & & & & & - \\
\hline
\end{tabular}
${ }^{*} p<.05 ;{ }^{* *} p<.01$.

Također, teža ekonomska prilagodba obitelji pokazala se povezanom i s manjom roditeljskom samoefikasnošću majke, ali ne i s roditeljskom samoefikasnošću oca. Depresivnije su se majke procjenjivale kao manje efikasne u roditeljskoj ulozi te je izraženija učestalost depresivnih simptoma kod majki bila povezana s izraženijim simptomima depresivnosti kod oca, kao i kod adolescenata. Nadalje, depresivniji očevi se procjenjuju manje efikasnima u ulozi oca, a oni, kao i majke, imaju izraženije depresivne simptome, što je povezano s izraženijom depresivnošću adolescenata.

\section{Rezultati serijalnih medijacijskih analiza}

Rezultati serijalnih medijacijskih analiza na uzorku majki pokazali su značajan izravan učinak teže obiteljske ekonomske prilagodbe na depresivnost adolescenata $\left(c^{\prime}=0.18 ; S E=0.07 ; t=2.49 ; p=.01 ; I P=0.04-0.32\right)$. Odnosno, pokazalo se da izraženija teža obiteljska ekonomska prilagodba značajno predviđa izraženiju depresivnost adolescenata, čime se odbacuje prva postavljena hipoteza rada. 
Slika 1. Odnos između teže ekonomske prilagodbe obitelji, depresivnosti roditelja $i$ njihove roditeljske samoefikasnosti te depresivnosti adolescenta

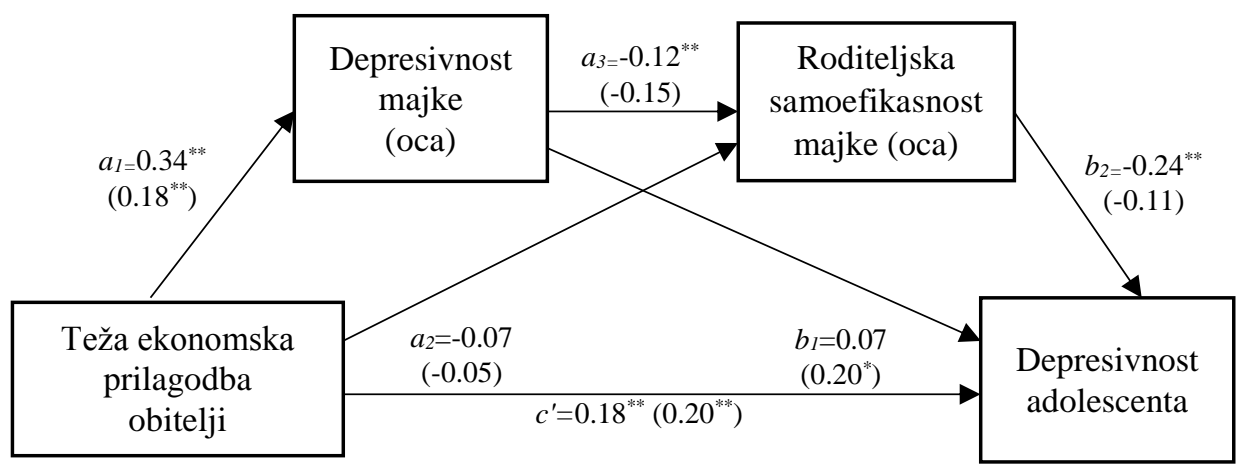

Napomena. U zagradama su prikazani podatci za oca $(N=241)$, a izvan zagrada podatci za majku $(N=239)$. Prikazani su nestandardizirani koeficijenti puteva $\left(a_{1}-\right.$ učinak teže ekonomske prilagodbe obitelji na depresivnost roditelja; $a_{2}$ - učinak teže ekonomske prilagodbe obitelji na roditeljsku samoefikasnost; $a_{3}$ - učinak depresivnosti roditelja na roditeljsku samoefikasnost; $b_{1}$ - učinak depresivnosti roditelja na depresivnost adolescenata; $b_{2}$ - učinak roditeljske samoefikasnosti na depresivnost adolescenta; $c^{\prime}$ - izravan učinak teže ekonomske prilagodbe obitelji na depresivnost adolescenta); ${ }^{*} p<.05 ;{ }^{* *} p<.01$.

Model obiteljskog stresa pretpostavlja da će otežana ekonomska prilagodba obitelji neizravno djelovati na depresivnost adolescenata preko roditeljske depresivnosti i roditeljske samoefikasnosti, što je također provjereno u ovom radu. Kada je riječ o majkama, dobiveni su rezultati pokazali važnost $(B=0.01 ; S E=0.01$; $I P=0.001-0.031$; Tablica 3.) neizravnoga serijalnog učinka teže obiteljske ekonomske prilagodbe na depresivnost adolescenata preko depresivnosti majke i njezine roditeljske samoefikasnosti. Kako je vidljivo iz Slike 1., otežana ekonomska prilagodba obitelji predviđa depresivnost majke $\left(a_{1}=0.34, p<.01\right)$, a povećana majčina depresivnost predviđa smanjenu roditeljsku samoefikasnost majke $\left(a_{3}=\right.$ $-0.12, p<.01)$, koja naposljetku značajno predviđa depresivnost kod adolescenata $\left(b_{2}=-0.24, p<.01\right)$. Prema dobivenim podatcima, potvrđena je druga hipoteza rada. Iako to nije bio problem rada, možemo spomenuti i rezultate vezane za ostala dva neizravna učinka koje testira PROCESS makro, onaj koji ide od teže ekonomske prilagodbe obitelji do depresivnosti adolescenata samo kroz majčinu depresivnost $\mathrm{i}$ onaj koji ide samo kroz majčinu roditeljsku samoefikasnost. Kako je vidljivo iz Tablice 3., pokazalo se da je, od ta dva neizravna učinka, značajan samo onaj koji ide kroz majčinu depresivnost $(B=0.02 ; S E=0.02 ; I P=0.002-0.072$; Tablica 3.). 
Tablica 3. Bootstraping podatci o veličini $i$ važnosti neizravnih učinaka teže ekonomske prilagodbe obitelji na depresivnost adolescenata kroz depresivnost roditelja i njihovu roditeljsku samoefikasnost

\begin{tabular}{|c|c|c|c|c|}
\hline Neizravni učinak kroz: & $B$ & $S E B$ & $\begin{array}{l}\text { 95\% IP } \\
\text { donji }\end{array}$ & $\begin{array}{l}95 \% \text { IP } \\
\text { gornji }\end{array}$ \\
\hline majčinu depresivnost & 0.02 & 0.03 & -0.027 & 0.083 \\
\hline majčinu roditeljsku samoefikasnost & 0.02 & $\mathbf{0 . 0 2}$ & 0.000 & 0.072 \\
\hline $\begin{array}{l}\text { majčinu depresivnost i roditeljsku } \\
\text { samoefikasnost }\end{array}$ & 0.01 & $\mathbf{0 . 0 1}$ & 0.001 & 0.031 \\
\hline očevu depresivnost & 0.04 & 0.03 & -0.002 & 0.098 \\
\hline očevu roditeljsku samoefikasnost & 0.01 & 0.01 & -0.004 & 0.041 \\
\hline očevu depresivnost i roditeljsku samoefikasnost & 0.00 & 0.00 & -0.006 & 0.012 \\
\hline
\end{tabular}

Napomena. Ako interval pouzdanosti (IP) ne uključuje nulu, radi se o značajnom neizravnom učinku. Značajni su učinci otisnuti podebljanim slovima.

Kada je riječ o očevima, rezultati serijalne medijacijske analize također su pokazali značajan izravan učinak teže obiteljske ekonomske prilagodbe na depresivnost adolescenata $\left(c^{\prime}=0.20 ; \quad S E=0.07 ; \quad t=2.79 ; \quad p=.01 ; \quad I P=0.06-0.33\right)$. Konkretnije, pokazalo se da izraženija teža ekonomska prilagodba obitelji značajno predviđa izraženiju depresivnost adolescenata, čime se odbacuje treća postavljena hipoteza rada. Za razliku od rezultata na uzorku majki, rezultati na uzorku očeva pokazali su neznačajnost neizravnoga serijalnog učinka teže obiteljske ekonomske prilagodbe na depresivnost adolescenata preko očeve depresivnosti i njegove roditeljske samoefikasnosti $(B=0.003 ; S E=0.003 ; I P=-0.006-0.012)$. U ovom se modelu značajnim pokazao jedino put od teže ekonomske prilagodbe obitelji na izraženiju očevu depresivnost $\left(a_{1}=0.18, p<.01\right)$, dok su ostala dva puta važna za utvrđivanje serijalne medijacije neznačajna (Slika 1.). Čak štoviše, rezultati su pokazali i irelevantnost ostalih dvaju neizravnih učinaka (samo kroz očevu depresivnost i samo kroz očevu roditeljsku samoefikasnost), koje PROCESS makro testira. Dobivenom se neznačajnošću testirane serijalne medijacije depresivnosti oca i njegove roditeljske samoefikasnosti u odnosu između teže ekonomske prilagodbe obitelji i depresivnosti adolescenata odbacuje četvrta postavljena hipoteza rada.

\section{Rasprava}

Za razliku od inozemne literature, u kojoj je zamjetan velik interes za proučavanje učinaka ekonomskih poteškoća na prilagodbu djece i mladih (npr. Conger i Elder, 1994; Conger i sur., 1992, 1993), u Hrvatskoj se može primijetiti nedostatak istraživanja te problematike. S obzirom na nepovoljne ekonomske prilike koje su u novije vrijeme zahvatile hrvatske obitelji, posve je jasno koliko je važno proučavati odnose između ekonomskih teškoća i ekonomskog pritiska, obiteljskih procesa i prilagodbe djece i mladih. Stoga je svrha ovog rada bila provjeriti odnose 
između otežane ekonomske prilagodbe, roditeljskih psiholoških poteškoća, njihove roditeljske samoefikasnosti i depresivnosti adolescenata na jednom prigodnom uzorku hrvatskih adolescenata i njihovih majki i očeva. U radu se pošlo od hipoteza temeljenih na postavkama modela obiteljskog stresa, a rezultati su općenito pokazali njihovu djelomičnu potvrdu na uzorku majki te njihovo potpuno odbacivanje na uzorku očeva.

Suprotno postavljenim hipotezama rada dobiveni su rezultati pokazali da teža ekonomska prilagodba pokazuje izravan učinak na depresivnost adolescenata na uzorku majki (odbacuje se H1), kao i na uzorku očeva (odbacuje se H3). Iako model obiteljskog stresa pretpostavlja da ekonomski pritisak, odnosno teža ekonomska prilagodba predviđa lošiju prilagodbu adolescenata neizravno putem svojih učinaka na iskustvo roditelja, u literaturi postoje dokazi i da ekonomski pritisak izravno predviđa lošiju prilagodbu adolescenata (Conger i sur., 2002; Taylor, Rodriguez, Seaton i Dominguez, 2004). Tijekom adolescencije psihološki su resursi kod mladih umanjeni jer u tom razdoblju doživljavaju određene normativne stresove, poput tjelesnih promjena te promjena u socijalnim i obiteljskim odnosima (Conger i Ge, 1999). U takvim uvjetima već oslabljenih psiholoških resursa, obiteljske stresne situacije, poput ekonomskog pritiska, mogu i izravno pridonijeti negativnim emocijama kod adolescenata, kao što su strah, ljutnja, bespomoćnost i frustracija (Lee i sur., 2013). Osim toga, mladi tijekom adolescencije postaju prijemčiviji na nepovoljne obiteljske okolnosti zbog značajnog povećanja salijentnosti obiteljskih ekonomskih resursa (Halpern-Felsher i sur., 1997). Chase-Lansdale i suradnici (2011) pronašli su da adolescenti s vremenom postaju sve više svjesni socijalnog i ekonomskog statusa svojih roditelja. Kako mladi postaju sve svjesniji manjka u obiteljskim financijskim resursima, sve više razmišljaju o ograničenjima koje im nameće taj manjak, zbog čega se naposljetku i povećava vjerojatnost javljanja problema u njihovu funkcioniranju (Taylor, Budescu, Gebre i Hodzic, 2014; Taylor i sur., 2004).

Osim izravnog učinka teže ekonomske prilagodbe obitelji na depresivnost adolescenata, u radu je provjereno i postoji li neizravan serijalan učinak teže ekonomske prilagodbe obitelji na depresivnost adolescenata kroz depresivnost roditelja i roditeljsku samoefikasnost, i to posebno na uzorku majki i uzorku očeva.

Na uzorku majki rezultati su potvrdili postojanje pretpostavljenoga neizravnoga serijalnog učinka, čime je potvrđena jedna polazna hipoteza rada (H2). Pokazalo se kako teža ekonomska prilagodba obitelji značajno predviđa izraženije depresivne simptome kod majki te da izraženija depresivnost majki značajno predviđa njihovu smanjenu roditeljsku samoefikasnost, što naposljetku predviđa izraženiju depresivnost adolescenata. Dobiveni su rezultati u skladu s postavkama modela obiteljskog stresa te dostupnim podatcima u literaturi (npr. Scaramella i sur., 2008). Scaramella i suradnici (2008) pokazali su da majčina percepcija ekonomskih teškoća pokazuje neizravan učinak na izraženije internalizirane (i eksternalizirane) probleme kod djeteta kroz dva serijalna medijatora - izraženiju depresivnost majke te njezinu 
smanjenu roditeljsku samoefikasnost. Međutim, važno je napomenuti kako je istraživanje Scaramelle i suradnika (2008) provedeno na majkama djece predškolskog uzrasta, za razliku od ovog istraživanja, koje je provedeno na uzorku adolescenata. Istraživanja (npr. Grant i sur., 2000) provedena na uzorcima adolescenata također uglavnom potvrđuju model obiteljskog stresa. Iako u većini njih nisu mjerene sve varijable koje su uključene u ovdje provjeravani model obiteljskog stresa, uvidom u odnose među pojedinim varijablama se može zaključiti kako su nalazi tih istraživanja sukladni nalazima dobivenim u ovom radu. Kao i u ovom radu, nalazi transverzalnog istraživanja koje su proveli Grant i sur. (2000) pokazali su da ekonomski pritisak obitelji značajno predviđa izraženiju depresivnost kod majki djece adolescentske dobi. Prema tome, ekonomski pritisak obitelji, odnosno neizvjesnost i nesigurnost ekonomski nepovoljne obiteljske situacije, može izazvati snažne negativne osjećaje kod majki, a jedan je od tih osjećaja depresija.

Depresivnost majki se često $\mathrm{u}$ istraživanjima pokazuje kao rizičan čimbenik depresivnosti kod djece (npr. Hammen i Brennan, 2003), što je potvrđeno i u našem istraživanju, jer je dobiveno da depresivnost majki izravno predviđa depresivnost adolescenata (odnosno, da je depresivnost majki značajan medijator u odnosu između teže ekonomske obiteljske prilagodbe obitelji i depresivnosti adolescenata). Osim da je značajan prediktor depresivnosti djece, za depresivnost roditelja često se u literaturi (npr. Freedman-Doan, Arbreton i Eccles, 1995) može naći i tvrdnja da je ona jedna od snažnijih odrednica roditeljske samoefikasnosti, što je potvrđeno na našem uzorku majki adolescenata. Ovdje je važno napomenuti kako osjećaj samoefikasnosti u roditeljskoj ulozi kod roditelja adolescenata može biti više narušen nego kod roditelja mlađe djece (Freedman-Doan, Arbreton, Harold i Eccles, 1993) te da se $\mathrm{u}$ istraživanjima pokazalo da početak puberteta kod djece može biti okidač strahova kod roditelja o njihovoj sposobnosti djelovanja na ponašanje djeteta (Buchanan i sur., 1990). Stoga i ne čudi nalaz ovog istraživanja da smanjena majčina roditeljska samoefikasnost značajno predviđa izraženiju depresivnost u mladih $\mathrm{u}$ razdoblju adolescencije, razdoblju u kojem se bilježi vrhunac javljanja depresivnih simptoma (Rudolph, 2008). Dobiveni je nalaz u skladu s polaznim hipotezama rada, kao i rezultatima većine istraživanja (npr. Robinson, Strahan, Girz, Wilson i Boachie, 2013) koji su pokazali da je majčina depresivnost jedan od najznačajnijih rizičnih čimbenika javljanja depresivnosti kod mladih u razdoblju adolescencije.

Međutim, ne možemo napustiti ovaj dio rasprave a da ne spomenemo neke važne činjenice oko konceptualizacije konstrukta roditeljske samoefikasnosti, a koje treba uzeti u obzir kada se donose zaključci o odnosima te varijable i emocionalnog stanja roditelja. Naime, u literaturi se mogu opaziti značajne nedosljednosti u nalazima istraživanja odnosa između depresivnosti roditelja i roditeljske samoefikasnosti. Tako su neka istraživanja (npr. Gross i Tucker, 1994; Scaramella i sur., 2008) pokazala da je depresivnost majki povezana s njihovim osjećajem roditeljske samoefikasnosti, dok neka druga (npr. Sevigny i Loutzenhiser, 2009) nisu potvrdila postojanje tog odnosa. Razlog tome može biti u različitim 
konceptualizacijama ovog konstrukta, a samim time i određenih razlika u mjerama koje se primjenjuju u istraživanjima. Kako navode Coleman i Karraker (2003), u literaturi postoje tri različita pristupa formulaciji roditeljske samoefikasnosti. Jedan se pristup odnosi na percepciju roditelja o vlastitim kompetencijama vezanim za specifične zadatke u domeni roditeljstva (npr. briga o djetetu kada ono ima vrućicu) (Coleman i Karraker, 2003). Drugi pristup, nazvan pristup "specifičan za domenu", uključuje kombinaciju podataka dobivenih mjerama samoefikasnosti specifičnih za zadatak. Primjerice, roditelji mogu biti zamoljeni da procijene svoje sposobnosti vezane za niz različitih pokazatelja discipliniranja djeteta, emocionalne podrške te tjelesnog zbrinjavanja. Nakon toga, informacije o efikasnosti dobivene na česticama pojedinih, specifičnih zadataka kombiniraju se u multidimenzionalni indeks roditeljske samoefikasnosti na razini domene. Treći pristup, poznat kao pristup "općenit za domenu", promatra roditeljsku samoefikasnost kao konceptualno različitu od samoefikasnosti u drugim domenama; međutim, njezino se mjerenje temelji na općenitim očekivanjima kompetentnosti koje nisu povezane sa specifičnim zadatcima roditeljstva. U ovom se istraživanju koristila mjera roditeljske samoefikasnosti iz trećega navedenog pristupa, odnosno pristupa "općenitog za domenu". Istu su takvu mjeru u svom istraživanju koristili i Scaramella i suradnici (2008), koji su na svom uzorku majki dobili rezultate koji su usporedivi s rezultatima dobivenim na našem uzorku majki. Dok je u našem istraživanju i istraživanju Scaramelle i suradnika (2008) depresivnost bila povezana sa smanjenom roditeljskom samoefikasnošću, u istraživanju koje su proveli Sevigny i Loutzenhiser (2009) to se nije potvrdilo. Međutim, važno je naglasiti da su Sevigny i Loutzenhiser (2009) koristili drugačiju mjeru roditeljske samoefikasnosti, odnosno mjeru koja se temelji na pristupu koji je "specifičan za domenu". Dakle, psihološka dobrobit roditelja može biti snažna odrednica njihova osjećaja roditeljske efikasnosti, ali je važno da se pri interpretiranju nalaza vezanih za roditeljsku samoefikasnost uzme u obzir i postojanje različitih konceptualizacija ovog konstrukta te da se u skladu s time donose oprezni zaključci o odnosu ovog konstrukta s konstruktima negativnih emocionalnih stanja kod roditelja.

Za razliku od podataka na uzorku majki, podatci na uzorku očeva nisu potvrdili polaznu pretpostavku rada (H3) temeljenu na modelu obiteljskog stresa. Naime, na uzorku očeva rezultati su pokazali irelevantnost provjeravanoga serijalnoga medijacijskog učinka teže ekonomske prilagodbe obitelji na depresivnost adolescenata. Iako to nije bio problema rada, možemo spomenuti i da su rezultati na uzorku očeva pokazali i neznačajnost neizravnog učinka teže obiteljske prilagodbe obitelji na depresivnost adolescenata samo kroz depresivnost roditelja kao i samo kroz roditeljsku samoefikasnost. Razmatrajući puteve uključene u provjeravani serijalni medijacijski učinak, vidljivo je da teža ekonomska prilagodba obitelji značajno predviđa depresivnost oca, ali da depresivnost oca ne predviđa značajno roditeljsku samoefikasnost oca, te da roditeljska samoefikasnost oca naposljetku ne predviđa značajno depresivnost adolescenata. Dakle, prvo što se može uočiti je da je put između očeve depresivnosti i očeve roditeljske samoefikasnosti neznačajan, što 
je suprotno rezultatima na uzorku majki. Za razliku od podataka u literaturi dobivenih na uzorku majki, podatci dobiveni na uzorku očeva dosljedno pokazuju da ne postoji povezanost depresivnih simptoma i roditeljske samoefikasnosti (npr. Gross i Tucker, 1994; Sevigny i Loutzenhiser, 2009). Tako su Gross i Tucker (1994) na uzorku očeva djece predškolskog uzrasta pokazali da depresivnost nije povezana s roditeljskom samoefikasnošću očeva, a Sevigny i Loutzenhiser (2009) su pokazali da depresivni simptomi ne predviđaju roditeljsku samoefikasnost očeva jednog uzorka djece predškolskog uzrasta. Navedeni rezultati sugeriraju da se dobiveni odnosi među varijablama mogu objasniti time što je, kao navode Sevigny i Loutzenhiser (2009), biti roditeljem salijentniji aspekt identiteta žene nego identiteta muškarca. Sukladno navedenom, u istraživanju koje su proveli Sevigny i Loutzenhiser (2009), pokazalo se da je mjera opće samoefikasnosti povezana s mjerom roditeljske samoefikasnosti kod majki, ali ne i kod očeva. Moguće je da očevi smatraju da su vještine potrebne za izvršavanje različitih roditeljskih zadataka različite od svladavanja izazova $u$ drugim domenama života. To može biti odraz ideologije odvojenih sfera, odnosno pojave da se majke većinom brinu oko djece i obiteljskog života, dok im očevi pružaju ispomoć u tome kroz izvršavanje zadataka. S obzirom na sve dosad navedeno o roditeljskoj samoefikasnosti kod očeva, ne iznenađuju ni rezultati ovog istraživanja vezani za posljednji put u provjeravanom serijalnom neizravnom učinku, a to je onaj od roditeljske samoefikasnosti do depresivnosti adolescenata. Kao i kod odnosa između depresivnosti oca i njegove roditeljske samoefikasnosti rezultati su i u ovom slučaju pokazali da roditeljska samoefikasnost oca ne predviđa značajno depresivnost adolescenata.

Provedeno istraživanje, kao i svako drugo, karakterizirano je nekim nedostatcima. Prije svega, ovo je istraživanje transverzalnog tipa, zbog čega ne možemo donositi uzročno-posljedične zaključke. Osim toga, nedostatak se odnosi i na to što je odaziv na sudjelovanje $u$ istraživanju bio relativno malen te da je moguće da su se na istraživanje odazvali samo oni sudionici koji smatraju da u mjerenim područjima nemaju problema. Također, $u$ istraživanju su korištene očeve i majčine samoprocjene depresivnosti i roditeljske samoefikasnosti. Zbog želje roditelja da se prikažu u što boljem svjetlu, samoprocjene su mogle pokazivati nižu razinu depresivnosti i višu razinu roditeljske samoefikasnosti. U budućim bi istraživanjima bilo dobro koristiti i procjene učitelja te osoba koje još žive u kućanstvu ili nezavisnih procjenjivača, što bi moglo povećati pouzdanost dobivenih podataka.

Usprkos nedostatcima ovaj rad ima značajne doprinose. Prvo svakako valja navesti vrijednost dobivenih podataka vezanih za provjeru postavki modela obiteljskog stresa na hrvatskom uzorku, čime se dodatno obogaćuje literatura o valjanosti ovog modela. Također, doprinos je rada vidljiv i u činjenici što je ovo jedno od rijetkih istraživanja koje je proučavalo konstrukt roditeljske samoefikasnosti u okviru neke teorije. Isto tako, značajan doprinos rada ogleda se i $\mathrm{u}$ tome što je konstrukt roditeljske samoefikasnosti u radu proučavan zasebno na uzorku majki i očeva adolescenata, što se izuzetno rijetko može naći u literaturi. 
Zaključno, dobiveni su rezultati pokazali da postoji razlika između mehanizma djelovanja teže ekonomske prilagodbe na depresivnost adolescenata na uzorku majki i mehanizma na uzorku očeva. Iako dobiveni rezultati imaju značajne teorijske implikacije, oni sugeriraju i da djelovanje na razini obiteljskih procesa može biti korisno pri mjerama intervencije kod depresivnosti adolescenata. Konkretnije, intervencije usmjerene na olakšavanje stresnih reakcija na ekonomske poteškoće kod majki i poticanje njihove roditeljske samoefikasnosti može djelomično smanjiti negativan učinak ekonomskog pritiska na depresivnost adolescenata. S druge strane, mjere intervencije usmjerene na smanjenje negativnih učinaka teže ekonomske prilagodbe koju percipiraju očevi na depresivnost adolescenata trebale bi uključivati neke druge čimbenike. Buduća bi se istraživanja trebala usmjeriti na pronalaženje tih čimbenika na uzorcima očeva daljnjim istraživanjima provjere različitih varijacija i proširenja modela obiteljskog stresa na hrvatskim uzorcima. Također, s obzirom na to da tijekom adolescencije djevojke češće počinju doživljavati depresivne simptome nego mladići (Hankin, Mermelstein i Roesch, 2007) te da učinci majčinih i očevih ponašanja i postupaka nisu identični prema sinovima i kćerima, buduća bi se istraživanja trebala usmjeriti i na proučavanje ovdje ispitivanih modela zasebno na uzorcima mladića i djevojaka.

\section{Literatura}

Ardelt, M. i Eccles, J.S. (2001). Effects of mothers' parental efficacy beliefs and promotive parenting strategies on inner-city youth. Journal of Family Issues, 22(8), 944-972.

Barnett, M. (2008). Economic disadvantage in complex family systems: Expansion of family stress models. Clinical Child and Family Psychology Review, 11(3), 145-161.

Baron, R.M. i Kenny, D.A. (1986). The moderator-mediator variable distinction in social psychology research: Conceptual, strategic and statistical considerations. Journal of Personality and Social Psychology, 51(6), 1173-1182.

Benić, Đ. (2012). Ekonomska kriza u Europi i hrvatsko gospodarstvo. Ekonomska misao i praksa, 21(2), 847-854.

Benner, A.D. i Kim, S.Y. (2010). Understanding Chinese American adolescnts' developmental outcomes: Insights from the family stress model. Journal of Research on Adolescence, 20(1), 1-12.

Berkowitz, L. (1989). Frustration-aggression hypothesis: Examination and reformulation. Psychological Bulletin, 106(1), 59-73.

Bolger, K.E., Patterson, C.J., Thompson, W.W. i Kupersmidt, J.B. (1995). Psychological adjustment among children experiencing persistent and intermittent family economic hardship. Child Development, 66(4), 1107-1129.

Buchanan, C.M., Eccles, J.S., Flanagan, C., Midgley, C., Feldlaufer, H. i Harold, R.D. (1990). Parents' and teachers' beliefs about adolescents: Effects of sex and experience. Journal of Youth and Adolescence, 19(4), 363-394. 
Chase-Lansdale, P., Cherlin, A.J., Guttmannova, K., Fomby, P., Ribar, D. i Coley, R. (2011). Long-term implications of welfarer eform for the development ofadolescents and young adults. Children and Youth Services Review, 33(5), 678-688.

Chorpita, B.F., Yim, L., Moffitt, C., Umemoto, L.A. i Francis, S.E. (2000). Assessment of symptoms of DSM-IV anxiety and depression in children: A revised child anxiety and depression scale. Behavior Research and Therapy, 38(2), 835-855.

Christiansen, S.L. i Palkovitz, R. (2001). Why the 'good provider' role still matters. Journal of Family Issues, 22(1), 84-106.

Coleman, P.K. i Karraker, K.H. (2000). Parenting self-efficacy among mothers of school-age children: Conceptualization, measurement, and correlates. Family Relations, 49(1), 13 24.

Coleman, P.K. i Karraker, K.H. (2003). Maternal self-efficacy beliefs, competence in parenting and toddlers behaviour and developmental status. Infant Mental Health Journal, 24(2), 126-148.

Conger, R.D., Conger, K.J., Elder, G.H., Lorenz, F.O., Simons, R.L. i Whitbeck, L.B. (1992). Family process model of economic hardship and adjustment of early adolescent boys. Child Development, 63(3), 526-541.

Conger, R.D., Conger, K.J., Elder, G.H.Jr., Lorenz, F.O., Simons, R.L. i Whitbeck, L.B. (1993). Family economic stress and adjustment of early adolescent girls. Developmental Psychology, 29(2), 206-219.

Conger, R.D., Conger, K.J. i Martin, M.J. (2010). Socioeconomic status, family processes, and individual development. Journal of Marriage and Family, 72(3), 685-704.

Conger, R.D. i Donnellan, M.B. (2007). An interactionist perspective on the socioeconomic context of human development. Annual Review of Psychology, 58(1), 175-199.

Conger, R.D. i Elder, G.H. Jr. (1994). Families in troubled times: Adapting to change in rural America. Hawthorne, NY: Aldine de Gruyter.

Conger, R.D. i Ge, X. (1999). Conflict and cohesion in parent-adolescent relations: Changes in emotional expression from early to mid-adolescence. U: M. Cox i J. Brooks-Gunn (Ur.), Conflict and cohesion in families: Causes and consequences (str. 185-206). Mahwah, NJ: Erlbaum.

Conger, R., Wallace, L., Sun, Y., Simons, R., McLoyd, V. i Brody, G. (2002). Economic pressure in African American families: A replication and extension of the family stress model. Developmental Psychology, 38(2), 179-193.

Državni zavod za statistiku (2016). Priopćenje za javnost u povodu predstavljanja rezultata istraživanja "Mapiranje $i$ procjena geografske raspodjele rizika od siromaštva $i$ socijalne isključenosti za mala područja RH". Preuzeto s http://www.dzs.hr/

Elder, G.H., Conger, R.D., Foster, E.M. i Ardelt, M. (1992). Families under economic pressure. Journal of Family Issues, 13(1), 5-37.

Evans, G.W. (2004). The environment of childhood poverty. American Psychologist, 59(2), 77-92. 
Freedman-Doan, C.R., Arbreton, A.J. i Eccles, J.S. (1995). Under my influence? Parent and family factors associated with parenting efficacy in the elementary years. Preuzeto $\mathrm{s}$ http://www.rcgd.isr.umich.edu/garp/articles/eccles95h.pdf.

Freedman-Doan, C.R., Arbreton, A.J., Harold, R.D. i Eccles, J.S. (1993). Looking forward to adolescence: mothers' and fathers' expectations for affective and behavioral change. Journal of Early Adolescence, 13(4), 472-502.

Gershoff, E.T., Aber, J.L., Raver, C.C. i Lennon, M.C. (2007). Income is not enaught: Incorporating material hardship into models of income associations with parenting and child development. Child Development, 78(1), 70-95.

Gottman, J.M. i Notarius, C.I. (2000). Decade review: Observing marital interaction. Journal of Marriage and the Family, 62(4),927-947.

Grant, K., Poindexter, L., Davis, T., Hyon Cho, M., McCormick, A. i Smith, K. (2000). Economic stress and psychological distress among urban African American adolescents, Journal of Prevention \& Intervention in the Community, 20(1-2), 25-36.

Gross, D. i Tucker, S. (1994). Parenting confidence during toddlerhood: A comparison of mothers and fathers. Nurse Practitioner, 19(10), 29-34.

Halpern-Felsher, B.L., Connell, J.P., Spencer, M.B., Aber, J.L., Duncan, G.J., Clifford, E., ... Cole, S.S. (1997). Neighborhood and family factors predicting educational risk and attainment in African American and White children and adolescents. U: J. BrooksGunn, G.J. Duncan i J.L. Aber (Ur.), Neighborhood poverty: Context and consequences for children (Vol. 1, str. 146-173). New York: Russell Sage Foundation.

Hammen, C. i Brennan, P. (2003). Severity, chronicity, and timing of maternal depression and risk for adolescent offspring diagnoses in a community sample. Archives of General Psychiatry, 60, 253-260.

Hankin, B.L., Mermelstein, R. i Roesch, L. (2007). Sex differences in adolescent depression: Stress exposure and reactivity models. Child Development, 78(1), 279-295.

Hayes, A.F. (2009). Beyond Baron and Kenny: Statistical mediation analysis in the new millennium. Communication Monographs, 76(4), 408-420.

Hayes, A.F. (2012). PROCESS: A versatile computational tool for observed variable moderation, mediation, and conditional process modeling. Preuzeto $\mathrm{s}$ http://www.afhayes.com/public/process2012.pdf.

Hayes, A.F., Preacher, K.J. i Myers, T.A. (2010). Mediation and the estimation of indirect effects in political communication research. U: E.P. Holbert i R.L. Holbert (Ur.), Sourcebook for political communication research: Methods, measures, and analytical techniques (str. 434-465). New York: Routledge.

Hrvatski zavod za zapošljavanje (2016). Godišnjak 2015. Preuzeto s http://www.hzz.hr/ UserDocsImages/HZZ_Godisnjak_2015.pdf

Jones, T.L. i Prinz, R.J. (2005). Potential roles of parental self-efficacy in parent and child adjustment: A review. Clinical Psychology Review, 25(3), 341-363. 
Keresteš, G., Brković, I. i Kuterovac-Jagodić, G. (2011). Doživljaj kompetentnosti u roditeljskoj ulozi i sukobi između roditelja i adolescenata. Suvremena psihologija, 14(1), 17-34.

Kim, K.J., Conger, R.D., Elder Jr., G.H. i Lorenz, F.O. (2003). Reciprocal influences between stressful life events and adolescent internalizing and externalizing behaviors. Child Development, 74(1), 127-143.

Lee, T.K., Wickrama, K.A.S. i Simons, L.G. (2013). Chronic family economic hardship, family processes ad progression of mental and physical health symptoms in adolescence. Journal of Youth and Adolescence, 42(6), 821-836.

Linver, M.R., Brooks-Gunn, J. i Kohen, D. (2002). Family processes as pathways from income to young children's development. Developmental Psychology, 38(5), 719-734.

Lovibond, S.H. i Lovibond, P.F. (1995). Manual for the depression anxiety stress scales (2. izdanje). Sydney: Psychology Foundation.

McDougall, J., King, G., De Wit, D.J., Miller, L.T., Hong, S., Offord, D.R., ... Meyer, K. (2004). Chronic physical health conditions and disability among Canadian school-aged children: A national profile. Disability and Rehabilitation, 26(1), 35-45.

McLeod, J.D. i Shanahan, M.J. (1996). Trajectories of poverty and children's mental health. Journal of Health and Social Behavior, 37(3), 207-220.

Mistry, R., Lowe, E., Benner, A. i Chien, N. (2008). Expanding the family economic stress model: Insights from a mixed-methods approach. Journal of Marriage and Family, 70(1), 196-209.

Mistry, R.S., Vandewater, E.A., Huston, A.C. i McLoyd, V.C. (2002). Economic well-being and children's social adjustment: The role of family process in an ethnically diverse low income sample. Child Development, 73(3), 935-951.

Ponnet, K. (2014). Financial stress, parent functioning and adolescent problem behavior: An actor-partner interdependence approach to family stress processes in low-, middle-, and high-income families. Journal of Youth and Adolescence, 43(10), 1752-1769.

Rajter, M. (2013). Obiteljski stresori i obilježja obitelji kao prediktori roditeljskog nasilja nad djecom. (Neobjavljena doktorska disertacija). Sveučilište u Zagrebu, Pravni fakultet, Zagreb.

Robinson, A.L., Strahan, E., Girz, L., Wilson, A. i Boachie, A. (2013). 'I know I can help you': Parental self-efficacy predicts adolescent outcomes in family-based therapy for eating disorders. European Eating Disorders Review, 21, 108-114.

Rudolph, K.D. (2008). Adolescent depression. U: I.H. Gotlib i C.L. Hammen (Ur.), Handbook of depression (str. 444-466). New York: Guilford Press.

Samaan, R.A. (2000). The influenced of race, ethnicity, and poverty on the mental health of children. Journal of Health Care for the Poor and Underserved, 11(1), 100-110.

Scaramella, L.V., Sohr-Preston, S.L., Callahan, K.L. i Mirabile, S.P. (2008). A test of the family stress model on toddler-aged children's adjustment among hurricane Katrina impacted and nonimpacted low-income families. Journal of Clinical Child \& Adolescence Psychology, 37(3), 530-541. 
Sevigny, P.R. i Loutzenhiser, L. (2009). Predictors of parenting self-efficacy in mothers and fathers of toddlers. Child: Care, Health and Development, 36(2), 179-189.

Solantaus, T., Leinonen, J. i Punamäki, R.L. (2004). Children's mental health in times of economic recession: Replication and extension of the family economic stress model in Finland. Developmental Psychology, 40(3), 412-29.

Taylor, R., Budescu, M., Gebre, A. i Hodzic, I. (2014). Family financial pressure and maternal and adolescent socioemotional adjustment: Moderating effects of Kin social support in low income African American families. Journal of Child and Family Studies, 23(2), 242-254.

Taylor, R., Rodriguez, A., Seaton, E. i Dominguez, A. (2004). Association of financial resources with parenting and adolescent adjustment in African American families. Journal of Adolescent Research, 19(3), 267-283.

Wadsworth, M. i Achenbach, T. (2005). Explaining the link between low socioeconomic status and psychopathology: Testing two mechanisms of the social causation hypothesis. Journal of Consulting and Clinical Psychology, 73(6), 1146-1153.

\title{
The Role of Parents' Depression and Parental Self-Efficacy in the Relationship between Economic Adjustment and Depression in Adolescents
}

\begin{abstract}
Based on the theoretical assumptions of Family Stress Model, the aim of the paper was to empirically examine whether the effect of family's economic adjustment on the severity of depression in adolescents is direct and/or indirect through depression of parents and parental self-efficacy. Data used in this paper were collected from adolescents $(N=247)$ who live in twoparent families, and their parents within the project "Parents' work, family economic hardship and well-being of parents and children". Children rated their depression, and parents rated their depression and parental self-efficacy as well as an economic adjustment that family had to make. To examine the existence of a direct and indirect effect of family's economic adjustment on depression in adolescents, two serial mediation analyses (one on the sample of fathers and one on the sample of mothers) were performed using the PROCESS macro for SPSS. The results of these analyses showed that difficult family's economic adjustment contributes to higher depression in adolescents directly and indirectly, through mothers' depression and low maternal self-efficacy. The indirect serial effect of family's economic adjustment on depression of adolescents through fathers' depression and parental self-efficacy, was not significant. The findings point to different processes by which economic adjustment affects parents and adolescents.
\end{abstract}

Keywords: Family stress model, depression, parental self-efficacy, adolescents 


\section{El papel de la depresión de los padres y de la autoeficacia parental en conexión con el ajuste económico y la depresión en los adolescentes}

\section{Resumen}

Partiendo de las suposiciones teóricas del modelo de estrés familiar, el objetivo de este trabajo fue comprobar empíricamente si el ajuste económico de la familia surte su efecto sobre el grado de la depresión directa y/o indirectamente a través del efecto sobre la depresión de los padres y el sentimiento de la autoeficacia parental. En el trabajo se analizan datos obtenidos de los adolescentes $(N=247)$ que viven en las familias biparentales y de ambos padres en el marco del proyecto "Trabajo de los padres, dificultades económicas en familia y el bienestar de padres e hijos". Los hijos evaluaron su depresión, mientras que los padres evaluaron tanto su depresión y autoeficacia parental, como su ajuste económico. Para verificar si el ajuste económico dificultoso surte efecto directo e indirecto en el grado de depresión, se llevaron a cabo dos análisis seriales de mediación (uno en la muestra de los padres y otro en la muestra de las madres) a través de la macro PROCES para SPSS. Los resultados de estos análisis demostraron que el ajuste económico dificultoso influye directa e indirectamente en la depresión en los adolescentes, pero sólo a través de la depresión más grave de la madre y su sentimiento reducido de la autoeficacia parental. No parece ser significativo el efecto serial indirecto del ajuste económico de la familia sobre la depresión en los adolescentes a través de la depresión y la autoeficacia parental del padre. Los hallazgos del trabajo indican varios procesos a través de los cuales el ajuste económico de la familia influye en la conducta y las reacciones de los padres y los adolescentes.

Palabras claves: modelo de estrés familiar, depresión, autoeficacia parental, adolescentes

Primljeno: 22.01.2017. 